MUSLIM RAP, HALAL SOAPS,

AND REVOLUTIONARY THEATER 
THIS PAGE INTENTIONALLY LEFT BLANK 


\section{MUSLIM RAP, HALAL SOAPS, AND REVOLUTIONARY THEATER}

Artistic Developments in the Muslim World

EDITED BY KARIN VAN NIEUWKERK

UNIVERSITY OF TEXAS PRESS 
Copyright (C) 20II by University of Texas Press

All rights reserved

Printed in the United States of America

First edition, 20II

Requests for permission to reproduce material from this work should be sent to:

Permissions

University of Texas Press

P.O. Box 7819

Austin, TX 78713-7819

www.utexas.edu/utpress/about/bpermission.html

(2) The paper used in this book meets the minimum requirements of ANSI/NIsO Z39.48-1992 (RI997) (Permanence of Paper).

LIBRARY OF CONGRESS CATALOGING-IN-PUBLICATION DATA

Muslim rap, halal soaps, and revolutionary theater : artistic developments in the Muslim world / edited by Karin van Nieuwkerk. — Ist ed.

p. $\mathrm{cm}$.

Includes bibliographical references and index.

ISBN 978-0-292-7268I-9 (cloth : alk. paper) — ISBN 978-0-292-73552-I (e-book)

I. Popular culture-Islamic countries. 2. Arts-Islamic countries. 3. Islam and art. 4. Islamic civilization-Western influences. 5. Muslims-Non-Muslim countries-Social conditions-2Ist century. I. Nieuwkerk, Karin van, I960DS35.62.M885 $201 \mathrm{I}$

$700.88^{\prime} 297-\mathrm{dc} 23$

2011021616 